\title{
CURRENT KNOWLEDGE ABOUT CARDIOMYOCYTES MATURATION AND ENDOGENOUS MYOCARDIAL REGENERATION. BACKGROUND TO APPLY THIS POTENTIAL IN HUMANS WITH END-STAGE HEART FAILURE
}

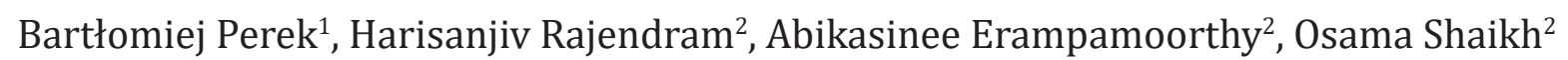

\begin{abstract}
Heart failure (HF) is a clinical status defined as a final stage of many cardiac diseases featured by severely impaired systolic myocardial performance in a result of dramatic decline in a number of properly functioning cardiomyocytes. Currently, the available therapeutic options for HF patients are not applicable in all of them. Up to now, many strategies to increase a number of normal cardiomyocytes have been proposed. One of them, the most physiological one at glance, seems to be a stimulation of post-mitotic cardiomyocytes to proliferate/or cardiac stem cells to differentiate. In this review article, detailed background of such method of myocardial regeneration, including the physiological processes of cardiomyocyte transformation and maturation, is presented. Moreover, the latest directions of basic research devoted to develop sufficient and safe cardiomyocyte-based therapies of the end-stage HF individuals are discussed. Concluding, this direction of further research seems to be justified particularly in a view of human population aging, an increased prevalence of HF and higher expectations of improved efficiency of patients' care.
\end{abstract}

Running title: Human cardiomyocytes and myocardial regeneration

Keywords: heart failure, cardiomyocytes, transformation, maturation, myocardial regeneration 


\section{Introduction}

Heart failure (HF) is a clinical status defined as a final stage of many cardiac diseases featured by severely impaired systolic myocardial performance in a result of dramatic decline in a number of properly functioning cardiomyocytes [1]. This is a consequence the human hearts respond to pathogenic factors such as infarction, inflammation and many others, with repair rather than regeneration [2]. The former one is featured by replacement of previously active myocytes with extracellular matrix (ECM), the main component of the fibrotic scar [3]. Phagocytosis of the injured cardiomyocytes by recruited monocytes has been suggested to initiate cardiac repair [4].

Currently, the only potentially available therapeutic options to improve significantly long-lasting functional status of HF patients either suffers from a painful shortage of the organ donors (heart transplantation) or are extremely expensive therefore with access only in the developed countries (the left ventricular assist devices, LVAD) [5,6]. The aforementioned facts encouraged/forced scientists of basic disciplines together with clinicians to search for the other methods to increase a number of properly functioning cardiomyocytes. Three possible solutions have raised in minds of researchers involved in human heart regeneration such as (i) injection of cardiomyocytes derived in vitro from human pluripotent stem cells (hPSC), (ii) in situ reprogramming of other cells (predominantly fibroblasts) into cardiomyocytes or (iii) stimulation of post-mitotic cardiomyocytes to proliferate/or cardiac stem cells to differentiate [7-9].

Of note, the latter strategy (iii), although the most physiological as mimic both physiological turnover of myocytes and cells divisions in the reaction to myocardial injury, is not the easiest one and, interestingly, rather new in comparison to the others mentioned above. We have thought for many years that cardiomyocytes permanently exit the cell cycle after birth, therefore effectively preventing a regenerative response. However, recent data suggest that there may be a persistent, but low, rate of new cardiac myocyte formation even in adult hearts [10]. The pool of cardiomyocytes that enter the cell cycle increases after myocardial injury. Unfortunately, the aforementioned process of cell self-renewal is usually insufficient to allow regeneration in the adult humans following acute and extensive damage (myocardial infarction, inflammation) [8,11]. On the other hand, there are clinical evidences that in particular patients and under special circumstances stimulation of cardiomyocytes to cell division (cytokinesis) is possible [12-15].

Herein, we review current basic knowledge that can serve as background for the development of future therapeutic strategies based on the intrinsic/ endogenous ability of cardiomyocytes to drive tis- sue regeneration. Moreover, we present, although scarce, clinical evidences that human heart can regeneration but only in the particular circumstances.

\section{Human heart growth and cardiomyocyte transformation and maturation}

Although 2-3 billion cardiomyocytes make up the majority of the heart mass (even up to 90\%) they account only for less than a third of the total cell number in the adult heart. Therefore, the human hearts growth depend on an increase in their mass but this process differs before and after birth. Generally, embryonic growth results from cardiomyocytes cell division (proliferation) leading to an increase in their number (defined as hyperplasia) while in the postnatal hearts predominantly due to their enlargement (called hypertrophy). Shortly after delivery, many myocytes undergo additional DNA synthesis not accompanied by cytokinesis, therefore a given number of cells become binucleated and tetraploid [15]. However, even after birth, proliferation of cardiomyocytes and progenitor differentiation still contribute to heart growth but only at a young age. Cardiomyocytes that are positive for a mitosis marker increase in the first 20 years of life, after which activity is low [16]. This is a consequence of human cardiomyocytes transformation and maturation. Understanding of them is essential for development of cardiomyocyte-based regenerative therapy.

The prenatal cardiomyocytes differ significantly from cells found in the adults hearts with many aspects [17-22]. The complex process of multi-level transformation from fetal to adult cardiomyocytes induced by many factors and rapidly changing human environment during delivery is obviously the most pronounced in this perinatal period [23-25].

\section{Subtypes of cardiomyocytes}

Fetal human cardiomyocytes are usually considered as immature cells [26] therefore different than adult ones with respect to histological appearance, transcriptomic profile and physiological properties [27]. Some authors even claimed that prenatal and adult cardiomyocytes could be considered as two distinct cell lines [28]. Neonatal are small and round whereas mature cardiomyocytes are bigger and fiber- or rod-shaped $[17,21,29]$. Contrary to the adult forms with highly aligned uniform sarcomeres, in the premature cells myofibers are embedded in cytoplasm in disarray $[17,18]$. Mitochondria in fetal myocytes are small, round, fragmented, immature and less numerous compared to the mature adult cells where they are large and ovular organelles capable of producing enough ATP to support the contractile function of the heart $[20,21]$. There are also significant differences in the nuclei. The vast majority of them in prenatal myocytes are mononucleated and diploid whereas in the postnatal period 
more cells become binucleated (in about 25\%) and polyploid (even in up to $75 \%$ ) with more than two homologous copies of chromosomes. It results from additional DNA synthesis not accompanied by cell division that takes place shortly after birth. Moreover, an increase in polyploidy and multinucleation is considered as not only normal aging but also typical response to myocardial injury [10].

Analysis of the transcriptomic profiles of sheep hearts, ontologically very close to the human ones, revealed that genes previously found as positive cell cycle regulators such as meis2, meis 3 , cyclin A and PCNA showed higher expression in fetal comparing to the adult hearts [30]. Genetic studies of contractile gene expression (for myosin heavy chains, MHC) revealed switch from the fetal (MHY7, beta) to the adult isoforms (MHY6, alpha) [31].

The mammalian fetal heart has immature cardiomyocytes, which are characterized by the naive property of proliferation during development, and shortly after birth they mostly exit their cell cycles resulting in very limited turnover in the adults (see below) $[26,32]$. Consequently, there is a much higher chance of regenerative capacity in neonatal cardiomyocytes compared with mature adult forms. The main metabolic substrate in the prenatal period is glucose and ATP is produced by means of glycolysis whereas metabolism of mature cardiomyocytes predominantly depends on the fatty acids that are utilized in oxidative phosphorylation process $[21,33,34]$. The latter one is considered as more efficient in ATP production [35]. Regarding electrophysiological properties, immature cardiomyocytes rely on extracellular calcium concentrations necessary for muscle contraction in contrast to adult's cardiomyocytes, which have abundant intracellular calcium in the sarcoplasmic reticulum [36]. In the adult but not in the embryonic cardiomyocytes, an extensive network of transverse tubules (T-tubules), plasma membrane invaginations are observed [19]. The aforementioned structures facilitate synchronized calcium release.

\section{CM transformation and maturation process}

The complex and not completely known transformation from embryonic to adult cardiomyocytes involves structural, metabolic and electrophysiological changes. The last stage of this multifactorial process is maturation that is completed even years after birth (particularly definite development of T-tubules) [17].

Neonates undergo abrupt environmental changes during the transitional circulation, which is affected by oxygen, metabolic and hormonal fluctuations. The heart in the perinatal period in exposed to dramatic and abrupt environmental changes. The immature cardiomyocytes must adapt to not only rapid hemodynamic changes with peripheral resistance (to pump blood efficiently to the systemic circulation) but also both metabolic (involving oxygen, glucose, insulin, fatty acids, lactate) and hormonal (glucocorticoids and thyroxin) fluctuations. Among the aforementioned factors, the most prevalent seems to be perinatal oxidative stress and DNA damage in a consequence of higher oxygen pressures than before birth [37]. They lead to withdraw of cardiomyocytes from cell cycle. This process must not be treated as negative but an adaptation to increased hemodynamic demands (see below). Cytokinesis is associated with disassembling of sarcomeres that inevitably lead to a loss of contractile function. On the other hand, increase in intracellular DNA content (in result of its duplication without cell division) was shown to enhance expression of contractile proteins and stronger pump performance but sacrificing self-renewal potential [38].

Cyclic mechanical force stretches cardiomyocytes soon after birth that results in changing cell shapes [24]. Dynamic mechanical stress on immature myocytes leads also to overexpression of cardiac markers and affects calcium handling. It has been revealed recently that activation of the cytoskeletal protein vinculin was essential for maturation of myofilament, which was linked to this mechano-transduction pathway [25]. One must not be forgotten that high oxygenation after delivery contribute substantially to cardiomyocytes maturation [23]. The clinical evidences have been collected that hypoxic status in the embryonic circulation is associated with delay in myocardial maturation. The environmental factors linked to hypoxic stress for fetus such as gestation in women living at high altitude, with anemia, cardiac or pulmonary defects or placental insufficiency have been reported to increase the prevalence of congenital heart defects $[39,40]$.

The mitochondria play a pivotal role in transition and maturation control. During maturation of cardiomyocytes they must secure sufficient production of ATP and sensing metabolic transitions [20]. This process is also regulated by Actn2-based sarcomeres that regulate the maturation of the other organelle with signal transduction and gene transcription [18].

The maturation of cardiomyocytes from immature fetal cardiomyocytes to mature forms involves: (1) myofibrillar maturation, including sarcomeric isoform switching from fetal to adult version; (2) maturation of electrophysiology and $\mathrm{Ca}^{2+}$ handling with expansion of the sarcoplasmic reticulum (SR) and T-tubule formation; (3) metabolic maturation with an increase in number and size of mitochondria; and (4) hypertrophy by increasing the volume of cardiomyocytes with formation of intercalated disks [18]. 


\section{Physiological cardiomyocyte turnover and self-regeneration}

Assessment of the total percentage of DNA synthesis by means of genomic ${ }^{14} \mathrm{C}$ incorporation in human cardiomyocytes revealed that their turnover decreased with age [41]. Myocytes renewal rate is the highest in the first decade of life (a rate of $0.8 \%$ $-1.0 \%$ at the age of 20 ) and declines to values of $<0.3 \%$ in the elderly. Of note, two peaks at $<1$ year of age and at approximately the prepubertal age have been noted [41]. These time points are correlated with children's growth spurt with dynamic changes in hormones.

Some evidences have been found that the low turnover rate resulted from proliferation of present cardiomyocytes (re-entry into the cell cycle) rather than differentiation of cardiac progenitor cells into cardiomyocytes [42-44]. However, some researchers still advocate that myocyte turnover in the adult heart originates from a pool of persistent cardioblasts [45].

Of interest, while cardiomyocyte numbers are relatively constant throughout life after the adolescent period, endothelial and mesenchymal cells increase into adulthood and show a high turnover rate.

Zhang et al. disclosed for the first time in vivo the ability of mammalian cardiac myocytes to dedifferentiate and reenter the cell cycle [46]. Earlier, investigators have claimed that mononuclear cardiac myocytes in mammals account for the cell activity seen in stimulated hearts (predominantly in the mouse models of myocardial infarction) $[47,48]$.

Some investigators still insist that endogenous progenitors give rise to new cardiac myocytes in the adult hearts [49]. Currently there are little data supporting presence but none functional role of endogenous progenitor cells in vivo in human hearts. Although they were visualized through co-expression of c-kit and Nkx 2.5 [49], the contribution of labeled endogenous c-kit cells was assessed as insignificantly small in the mature adult heart even after injury [50].

\section{Clinical evidences of injured heart regeneration}

There are, although very few reports (usually as descriptions of the exceptional clinical cases) dealing with human heart regeneration $[12,14]$. In one of them, Haubner et al. reported a case of a newborn child with severe myocardial ischemia due to occluding thrombus in the left anterior descending artery (LAD) [12]. Transmural ischemia was confirmed by electrocardiography (ECG). Additionally, echocardiography showed severe impairment of left ventricular contractility and high concentration of troponin $\mathrm{T}$ in laboratory examinations. Following the procedure of thrombolysis, of note performed approximately 28 hours after the first symptoms of $\mathrm{HF}$, the myocardium recovered completely. At 1-year follow-up examination, no symptoms of $\mathrm{HF}$ and signs of previous myocardial transmural myocardial infarction in any cardiological examinations (ECG, echocardiography) were found.

The aforementioned case was supported by the clinical outcomes of the neonatal patients who were operated due to anomalous origin of the left coronary artery from the pulmonary artery (ALCAPA) $[14,51]$. Before surgery many of them presented severe left ventricular systolic dysfunction due to ischemia (as a result of myocardial perfusion with venous blood) and required inotropic support. In Bakhtiary et al. study $28 \%$ of neonates had signs of MI before surgical correction but in the vast majority (approximately 90\%) of them left ventricular function normalized following cardiac surgical intervention. They concluded that establishment of a two-coronary artery system artery resulted in complete recovery of left ventricular function [14]. In the another report devoted to scar tissue fate following successful correction of ALCAPA [51], Fratz et al showed severely compromised left ventricular function and evidences of scarring before corrective surgery, whereas in long-term follow-up the scar tissue was relatively scarce. Among possible speculative theories they mentioned about higher cardiomyocytes turnover rate following surgical correction of heart vasculature, particularly in young human hearts exposed before operation for permanent ischemia.

\section{Future strategies of promotion of cardiomyocyte proliferation and myocardial regeneration}

Up to now, many strategies have been developed to regain proliferative capacity of adult cardiomyocytes. Some of them were effective in vitro but when applied iv vivo, particularly in the small rodents experimental model they failed to regenerate myocardium. The following directions on the strategies with 'regenerative' potential have been proposed:

- manipulation on the activity of cell cycle stimulators. As positive cell cycle regulators are in majority downregulated after completion of the cardiomyocytes transformation and maturation processes, reverse cell cycle arrest may enable/promote cardiomyocytes proliferation and cardiac regeneration [52]. Unfortunately many of them were shown to induce DNA synthesis that was not followed by cytokinesis [53]. Therefore it resulted in cardiomyocytes multinucleations but not substantial increase in cell number. Recently, an efficiency of cocktail of four cell cycle regulators such as cyclin CCNB and CCND together with cyclin-dependent kinase-1 (CDK-1) and -4 (CDK-4) has been noted [54].

- application of the developmental signaling pathways such as Hedgehog or Hippo/YAP (Yes-as- 
sociated protein) and/or developmental transcription factors (acting as the crucial regulators of myocyte proliferation) such as meis1, E2F family(-1, -2, -3) [55-58].

- employment of the hypoxic myocardial response. During the onset of HF featured by tissue hypoxia, several signatures are observed in cardiomyocytes that includes fetal reprogramming of gene expression where adult genes are repressed and fetal genes turned on [59]. Having in mind that embryonic cardiomyocytes have ability to divide and through proliferation increase the number of properly functioning cells $[15,16]$, this scientific proof of 'reverse transformation', at least at the genomic level, may be applied as one of the possible methods of cellular-based HF therapy. In vitro studies on the adult mice revealed reactivation of cardiomyocytes mitosis and myocardial regeneration after experimental injury [60].

- reactivation of cardiomyocyte cell cycle with paracrine factors (eg., growth factors, cytokines) secreted by other non-cardiomyocyte cells that create microenvironment optimal for local hemostasis, including also regulation of myocytes proliferation. Several factors such as fibroblast growth factor 1 and 2 (FGF1 and FGF2), hepatocyte growth factor (HGF), growth hormone-releasing hormone agonist (GHRH), follistatin-like 1, selected interleukins (IL6 and IL13) and many others have been found to stimulate myocyte cell-cycle reentry [61-64]. Of interest, experimental in vivo models revealed also how important is the source (produced and released locally or injected) as well as delivery method of the signaling molecules [65].

- control of cardiomyocyte regeneration by intervention in miRNA network. Several miRNAs-based (eg. MiR-15, miR-199a, miR-222, miR-590) treatments have been demonstrated to promote myocytes proliferation or cardiac repair but accompanied by reduced fibrosis and scar formation $[66,67]$.

\section{Potential danger of cellular-based therapies}

Although the approach of restoration of myocardial systolic function enables true regeneration of human hearts as stimulate and/or accelerate intrinsic mechanisms, it must not be considered as completely safe. A such deep interventions in the cellular genome and/or transcription process have potential to cause very serious consequences therefore they application must be particularly careful and strictly controlled. If poorly controlled and unrestricted may promote neoplastic transformation and tumor formation (tumorigenesis) [68]. The strategies that involved application of miRNA if related to uncontrolled expression of some of them led to sudden arrhythmic death of the most experimental animals in some series [69].

\section{Conclusions}

Cardiomyocytes or cardiomyoblast-based regeneration therapy although considered as the most physiological method to restore sufficiently the adequate number of properly functioning cardiac muscle cells, is still far from clinical application. However, this direction of further research seems to be justified particularly in a view of human population aging, an increased prevalence of HF and higher expectations of improved efficiency of our treatment.

\section{Ethical approval}

The conducted research in a form of review article is not related to either human or animal use. Therefore, the authors have not applied for Local Bioethical Committee for study approval.

\section{Acknowledgements}

Not applicable.

\section{Corresponding author}

Bartłomiej Perek, Department of Cardiac Surgery and Transplantology, Poznan University of Medical Sciences, 1/2 Długa Str, 61848 Poznań, Poland, phone: +48 618549 210, e-mail: bperek@ ump.edu.pl.

\section{Conflict of interest}

The authors declare they have no conflict of interest.

\section{References}

1. Rota M, Leri A, Anversa P. Human heart failure: is cell therapy a valid option? Biochem Pharmacol. 2014;88(2):129-38; D0I:10.1016/j. bcp.2013.10.031.

2. Zietkiewicz M, Perek B, Meyns B, Mesotten L, Dispersyn G, Nishimura Y, Flameng W. Chronic heart failure model induced by coronary embolization in sheep. Int J Artif Organs. 1999;22(7):499-504.

3. Laflamme MA, Murry CE. Heart regeneration. Nature. 2011;473(7347):326-35; DOI:10.1038/nature10147.

4. Epelman S, Lavine KJ, Beaudin AE, Sojka DK, Carrero JA, Calderon B, Brija T, Gautier EL, Ivanov S, Satpathy AT, Schilling JD, Schwendener R, Sergin I, Razani B, Forsberg EC, Yokoyama WM, Unanue ER, Colonna M, Randolph GJ, Mann DL. Embryonic and adult-derived resident cardiac macrophages are maintained through distinct mechanisms at steady state and during inflammation. Immunity. 2014;40(1):91-104; DOI:10.1016/j.immuni.2013.11.019.

5. Fuchs M, Schibilsky D, Zeh W, Berchtold-Herz M, Beyersdorf F and Siepe M. Does the heart transplant have a future? Eur J Cardiothorac Surg. 2019;55(Suppl 1): i38-48; DOI:10.1093/ejcts/ezz107.

6. Sajgalik P, Grupper A, Edwards BS, Kushwaha SS, Stulak JM, Joyce DL, Joyce LD, Daly RC, Kara T, Schirger JA. Current status of left ventricular assist device therapy. Mayo Clin Proc. 2016;91(7):927-40; DOI:10.1016/j.mayocp.2016.05.002

7. Breckwoldt $\mathrm{K}$, Weinberger $\mathrm{F}$, Eschenhagen $\mathrm{T}$. Heart regeneration. Biochim Biophys Acta. 2016;1863(7 Pt B):1749-59; DOI:10.1016/j. bbamcr.2015.11.010.

8. Waring CD, Vicinanza C, Papalamprou A, Smith AJ, Purushothaman S, Goldspink DF, Nadal-Ginard B, Torella D, and Ellison. The adult heart responds to increased workload with physiologic hypertrophy, cardiac stem cell activation, and new myocyte formation. Eur Heart J. 35(39):2722-31; DOI:10.1093/eurheartj/ehs338.

9. Li SC, Wang L, Jiang H, Acevedo J, Chang AC, Loudon WG. Stem cell engineering for treatment of heart diseases: potentials and challenges. Cell Biol Int. 209;33:255-67; DOI:10.1016/j.cellbi.2008.11.009.

10. Zhang Y, Mignone J, MacLellan WR. Cardiac regeneration and stem cells. Physiol Rev. 2015;95(4):1189-204; DOI:10.1152/ physrev.00021.2014.

11. Xin M, Olson EN, Bassel-Duby R. Mending broken hearts: cardiac development as a basis for adult heart regeneration and repair. Nat Rev Mol Cell Biol. 2013;14(8):529-41; DOI:10.1038/nrm3619.

12. Haubner BJ, Schneider J, Schweigmann U, Schuetz T, Dichtl W, Velik-Salchner C, Stein JI, Penninger JM. Functional recovery of a human neonatal heart after severe myocardial infarction. Circ Res. 2016;118(2):216-21; DOI:10.1161/CIRCRESAHA.115.307017. 
13. Deutsch MA, Cleuziou J, Noebauer C, Eicken A, Vogt M, Hoerer J, Lange $\mathrm{R}$, Schreiber C. Successful management of neonatal myocardial infarction with ECMO and intracoronary r-tPA lysis. Congenit Heart Dis 2014;9(5):E169-74; DOI:10.1111/chd.12117.

14. Bakhtiary F, Mohr FW, Kostelka M. Midterm outcome after surgical correction of anomalous left coronary artery from pulmonary artery. World J Pediatr Congenit Heart Surg. 2011;2(4):550-3 DOI:10.1177/2150135111413615.

15. Soonpaa MH, Kim KK, Pajak L, Franklin M, Field LJ. Cardiomyocyte DNA synthesis and binucleation during murine development. Am J Physiol. 1996;271(1 Pt 1):C235-41; DOI:10.1152/ajpcell.1996.271.1.C235.

16. Mollova M, Bersell K, Walsh S, Savla J, Das LT, Park SY, Silberstein LE, Dos Remedios CG, Graham D, Colan S, Kühn B. Cardiomyocyte proliferation contributes to heart growth in young humans. Proc Natl Acad Sci USA. 2013;110(4):1446-51; DOI:10.1073/pnas.1214608110.

17. Guo Y, Pu WT. Cardiomyocyte maturation: new phase in development. Circ Res. 2020;126:1086-106(8); DOI:10.1161/ CIRCRESAHA.119.315862.

18. Guo Y, Cao Y, Jardin BD, Sethi I, Ma Q, Moghadaszadeh B, Troiano EC, Mazumdar N, Trembley MA, Small EM, Yuan GC, Beggs AH, Pu WT. Sarcomeres regulate murine cardiomyocyte maturation through MRTFSRF signaling. Proc Natl Acad Sci USA. 2021;118(2):e2008861118 DOI:10.1073/pnas.2008861118.

19. Guo Y, Jardin BD, Zhou P, Sethi I, Akerberg BN, Toepfer CN, Ai Y, Li Y Ma Q, Guatimosim S, Hu Y, Varuzhanyan G, VanDusen NJ, Zhang D, Chan DC, Yuan GC, Seidman CE, Seidman JG, Pu WT. Hierarchical and stage-specific regulation of murine cardiomyocyte maturation by serum response factor. Nat Commun. 2018;9(1):3837; DOI:10.1038/ s41467-018-06347-2.

20. Garbern JC, Lee RT. Mitochondria and metabolic transitions in cardiomyocytes: lessons from development for stem cell-derived cardiomyocytes. Stem Cell Res Ther. 2021;12(1):177; DOI:10.1186/ s13287-021-02252-6.

21. Dorn GW, Vega RB, Kelly DP. Mitochondrial biogenesis and dynamics in the developing and diseased heart. Genes Dev. 2015;29(19):1981-91; DOI:10.1101/gad.269894.115.

22. Gibb AA, Hill BG. Metabolic coordination of physiological and pathological cardiac remodeling. Circ Res. 2018;123:107-28; DOI:10.1161/ CIRCRESAHA.118.312017.

23. Hines MH. Neonatal cardiovascular physiology. Semin Pediatr Surg 2013;22(4):174-8; DOI:10.1053/j.sempedsurg.2013.10.004.

24. Taber LA. Biomechanics of cardiovascular development. Annu Rev Biomed Eng. 2001;3:1-25; DOI:10.1146/annurev.bioeng.3.1.1.

25. Fukuda R, Gunawan F, Ramadass R, Beisaw A, Konzer A, Mullapudi ST, Gentile A, Maischein MH, Graumann J, Stainier DYR. Mechanical forces regulate cardiomyocyte myofilament maturation via the VCL-SSH1-CFL axis. Dev Cell. 2019;51(1):62-77.e5; D0I:10.1016/j. devcel.2019.08.006

26. Galdos FX, Guo Y, Paige SL, VanDusen NJ, Wu SM, Pu WT. Cardiac regeneration: Lessons from development. Circ Res. 2017;120(6):941-59. DOI:10.1161/CIRCRESAHA.116.309040.

27. Maroli G, Braun T. The long and winding road of cardiomyocyte maturation. Cardiovasc Res. 2021;117(3):712-6; DOI: 10.1093/cvr/ cvaa159.

28. Quaife-Ryan GA, Sim CB, Ziemann M, Kaspi A, Rafehi H, Ramialison M, El-Osta A, Hudson JE, Porrello ER. Multicellular transcriptional analysis of mammalian heart regeneration. Circulation. 2017;136(12):1123 39; DOI:10.1161/CIRCULATIONAHA.117.028252.

29. Bray MA, Sheehy SP, Parker KK. Sarcomere alignment is regulated by myocyte shape. Cell Motil Cytoskeleton. 2008;65(8):641-51. DOI:10.1002/cm.20290

30. Locatelli P, Belaich MN, López AE, Olea FD, Uranga Vega M, Giménez CS Simonin JA, Bauzá MDR, Castillo MG, Cuniberti LA, Crottogini A, Cerrudo CS, Ghiringhelli PD. Novel insights into cardiac regeneration based on differential fetal and adult ovine heart transcriptomic analysis. Am J Physiol Heart Circ Physiol. 2020;318(4):H994-1007; DOI:10.1152/ ajpheart.00610.2019.

31. Weiss A, and Leinwand LA. The mammalian myosin heavy chain gene family. Annu Rev Cell Dev Biol. 1996;12:417-39; DOI:10.1146/annurev.cellbio.12.1.417.

32. Bergmann O, Bhardwaj RD, Bernard S, Zdunek S, Barnabé-Heider F, Walsh S, Zupicich J, Alkass K, Buchholz BA, Druid H, Jovinge S, Frisén J. Evidence for cardiomyocyte renewal in humans. Science. 2009;324(5923):98-102; DOI:10.1126/science.1164680.

33. Jiang Y, Park P, Hong SM, Ban K. Maturation of cardiomyocytes derived from human pluripotent stem cells: current strategies and limitations Mol Cells. 2018;41(7):613-21; DOI:10.14348/molcells.2018.0143.
34. Yang X, Pabon L, Murry CE. Engineering adolescence: Maturation of human pluripotent stem cell-derived cardiomyocytes. Circ Res. 2014;114(3):511-23; DOI:10.1161/CIRCRESAHA.114.300558.

35. Kreipke RE, Wang Y, Miklas JW, Mathieu J, Ruohola-Baker H. Metabolic remodelling in early development and cardiomyocyte maturation. Semin Cell Dev Biol. 2016;52:84-92; DOI:10.1016/j.semcdb.2016.02.004.

36. Seok H, Oh JH. Hypertrophic cardiomyopathy in infants from the perspective of cardiomyocyte maturation. Korean Circ J. 2021;51(9):73351; DOI:10.4070/kcj.2021.0153.

37. Puente BN, Kimura W, Muralidhar SA, Moon J, Amatruda JF, Phelps KL, Grinsfelder D, Rothermel BA, Chen R, Garcia JA, Santos CX, Thet S, Mori E, Kinter MT, Rindler PM, Zacchigna S, Mukherjee S, Chen DJ, Mahmoud AI, Giacca M, Rabinovitch PS, Aroumougame A, Shah AM, Szweda LI, Sadek HA. The oxyden-rich postnatal environment induces cardiomyocyte cell-cyle arrest through DNA damage responses. Cell 2014;157(3):56579; DOI:10.1016/j.cell.2014.03.032.

38. O’Tierney PF, Anderson DF, Faber JJ, Louey S, Thornburg KL, Giraud GD Reduced systolic pressure load decreases cell-cycle activity in the fetal sheep heart. Am J Physiol Regul Integr Comp Physiol. 2010;299(2):R5738; DOI:10.1152/ajpregu.00754.2009.

39. Stout K. Pregnancy in women with congenital heart disease: The importance of evaluation and counselling. Heart. 2005;91(6):713-4; DOI:10.1136/hrt.2004.047886.

40. ergmann O, Zdunek S, Felker A, Salehpour M, Alkass K, Bernard S, Sjostrom SL, Szewczykowska M, Jackowska T, Dos Remedios C, Malm T, Andrä M, Jashari R, Nyengaard JR, Possnert G, Jovinge S, Druid H, Frisén J. Dynamics of cell generation and turnover in the human heart. Cell. 2015;161(7):1566-75; DOI:10.1016/j.cell.2015.05.026

41. Senyo SE, Steinhauser ML, Pizzimenti CL, Yang VK, Cai L, Wang M, Wu TD, Guerquin-Kern JL, Lechene CP, Lee RT. Mammalian heart renewal by pre-existing cardiomyocytes. Nature. 2013;493(7432):433-6; DOI:10.1038/nature11682.

42. Walsh S, Ponten A, Fleischmann BF, Jovinge S. Cardiomyocyte cell cycle control and growth estimation in vivo--an analysis based on cardiomyocyte nuclei. Cardiovasc Res. 2010;86(3):365-73; DOI:10.1093/cvr/ cvq005.

43. Hosoda T, Rota M, Kajstura J, Leri A, Anversa P. Role of stem cells in cardiovascular biology. J Thromb Haemost. 2011;9(Suppl 1):151-61; DOI:10.1111/j.1538-7836.2011.04363.x.

44. Malliaras K, Ibrahim A, Tseliou E, Liu W, Sun B, Middleton RC, Seinfeld J, Wang L, Sharifi BG, Marbán E. Stimulation of endogenous cardioblasts by exogenous cell therapy after myocardial infarction. EMBO Mol Med. 2014;6(6):760-77; DOI:10.1002/emmm.201303626.

45. Zhang Y, Li TS, Lee ST, Wawrowsky KA, Cheng K, Galang G, Malliaras K, Abraham MR, Wang C, Marbán E. Dedifferentiation and proliferation of mammalian cardiomyocytes. PLoS One. 2010;5(9):e12559: DOI:10.1371/journal.pone.0012559.

46. Bersell K, Arab S, Haring B, Kühn B. Neuregulin1/ErbB4 signaling induces cardiomyocyte proliferation and repair of heart injury. Cell. 2009;138:257-70; DOI:10.1016/j.cell.2009.04.060.

47. Malliaras K, Zhang Z, Seinfeld J, Galang G, Tseliou E, Cheng K, Sun B, Aminzadeh M, Marban E. Cardiomyocyte proliferation and progenitor cell recruitment underlie therapeutic regeneration after myocardial infarction in the adult mouse heart. EMBO Mol Med. 2013;5(2):191-09; DOI:10.1002/emmm.201201737.

48. Urbanek K, Quaini F, Tasca G, Torella D, Castaldo C, Nadal-Ginard B, Leri A, Kajstura J, Quaini E, Anversa P. Intense myocyte formation from cardiac stem cells in human cardiac hypertrophy. Proc Natl Acad Sci USA. 2003;100(18):10440-5; DOI:10.1073/pnas.1832855100.

49. van Berlo JH, Kanisicak O, Maillet M, Vagnozzi RJ, Karch J, Lin SC, Middleton RC, Marbán E, Molkentin JE. c-kit+ cells minimally contribute cardiomyocytes to the heart. Nature. 2014;509(7500):337-41; DOI:10.1038/ nature13309.

50. Fratz S, Hager A, Schreiber C, Schwaiger M, Hess J, Stren HC. Long-term myocardial scarring after operation for anomalous left coronary artery from the pulmonary artery. Ann Thorac Surg. 2011;92(5):1761-5; DOI:10.1016/j.athoracsur.2011.06.021.

51. Di Stefano V, Giacca M, Capogrossi MC, Crescenzi M, Martelli F. Knockdown of cyclin-dependent kinase inhibitors induces cardiomyocyte re-entry in the cell cycle. J Biol Chem. 2011;286(10):8644-54; DOI:10.1074/jbc.M110.184549

52. Tane S, Ikenishi A, Okayama H, Iwamoto N, Nakayama KI, Takeuchi T. CKD inhibitors, p21(Cip1) and p27(Kip1), participate in cell cycle exit of mammalian cardiomyocytes. Bioche. Biophys Res Commun 2014;443(3):1105-9; DOI:10.1016/j.bbrc.2013.12.109.

53. Mohamad TMA, Ang YS, Radzinsky E, Zhou P, Huang Y, Elfenbein A Foley A, Magnitsky S, Srivastava G. Regulation of cell cycle to stimu- 
late adult cardiomyocyte proliferation and cardiac regeneration. Cell. 2018;173(1):104-16 e12; DOI:10.1016/j.cell.2018.02.014.

54. Singh BN, Koyano-Nakagawa N, Gong W, Moskowitz IP, Weaver CV, Braunlin E, Das S, van Berlo JH, Garry MG, Garry DJ. A conserved HHGli1-Mycn network regulates heart regeneration from newt to human. Nat Commun. 2018;9(1):4237; DOI:10.1038/s41467-018-06617-z.

55. Leach JP, Heallen T, Zhang M, Rahmani M, Morikawa Y, Hill MC, Segura A, Willerson JT, Martin JF. Hippo pathway deficiency reverses systolic heart failure after infarction. Nature. 2017;550(7675):260-4; DOI:10.1038/ nature24045.

56. Mahmoud AI, Kocabas F, Muralidhar SA, Kimura W, Koura AS, Thet $\mathrm{S}$ Porrello ER, Sadek HA. Meis 1 regulates postnatal cardiomyocyte cell cycle arrest. Nature. 2013;497(7448):249-53; DOI:10.1038/nature12054.

57. Attwooll C, Lazzerini Denchi E, Hellin K. The E2F family: specific functions and overlapping interests. EMBO J. 2004;23(24):4709-16; DOI:10.1038/sj.emboj.7600481.

58. Bachhawat AK, Yadav S, Jainarayanan AK, Dubey P. Heart failure and the glutathione cycle: an integrated view. Biochem J. 2020;477(17):3123 30; DOI:10.1042/BCJ20200429.

59. Nakada Y, Canseco DC, Thet S, Abdisalaam S, Asaithamby A, Santos CX, Shah AM, Zhang H, Faber JE, Kinter MT, Szweda LI, Xing C, Hu Z Deberardinis RJ, Schiattarella G, Hill JA, Oz O, Lu Z, Zhang CC, Kimura W, Sadek HA. Hypoxia induces heart regeneration in adult mice. Nature. 2017;541(7636):222-7; DOI:10.1038/nature20173.

60. Engel FB, Hsieh PC, Lee RT, Keating MT. FGF1/p38 MAP kinase inibitor therapy induces cardiomyocyte mitosis, reduces scarringm and rescues function after myocardial infarction. Proc Natl Acad Sci USA. 2006;103(42):15546-51; DOI:10.1073/pnas.0607382103.

61. Koudstaal S, Bastings MM, Feyen DA, Waring CD, van Slochteren FJ, Dankers PY, Torella D, Sluijter JP, Nadal-Ginard B, Doevendans PA, Ellison GM, Chamuleau SA. Sustain delivery of insulin-like growth factor-1/ hepatocyte growth factor stimulates endogenous cardiac repair in the chronic infarcted pig heart. J Cardiovasc Transl Res. 2014;7(2):232-41 DOI:10.1007/s12265-013-9518-4.

62. Ouchi N, Oshima Y, Ohashi K, Higuchi A, Ikegami C, Izumiya Y, Walsh K. Follistin-like 1, a secreted muscle protein, promotes endothelial cell function and revascularization in ischemic tissue through a nitric-oxide synthase-dependent mechanism. J Biol Chem. 2008;283(47):32802-11; DOI:10.1074/jbc.M803440200.

63. O'Meara CC, Wamstad JA, Gladstone RA, Fomovsky GM, Butty VL, Shrikumar A, Gannon JB, Boyer LA, Lee RT. Transcriptional reversion of cardiac myocyte fate during mammalian cardiac regeneration. Cir. Res. 2015;116(5):804-15; DOI:10.1161/CIRCRESAHA.116.304269.

64. Wei K, Serpooshan V, Hurtado C, Diez-Cunado M, Zhao M, Maruyama S, Zhu W, Fajardo G, Noseda M, Nakamura K, Tian X, Liu Q, Wang A, Matsuura Y, Bushway P, Cai W, Savchenko A, Mahmoudi M, Schneider MD, van den Hoff MJ, Butte MJ, Yang PC, Walsh K, Zhou B, Bernstein D, Mercola M, Ruiz-Lozano P. Epicardial FSTL1 reconstruction regenerates the adult mammalian heart. Nature. 2015;525(7570):479-85; DOI:10.1038/ nature 15372 .

65. van Rooij E, Olson EN. MicroRNA therapeutics for cardiovascular disease: opportunities and obstacles. Nat Rev Drug Discov. 2012;11(11):860-72; DOI:10.1038/nrd3864.

66. Liu X, Xiao J, Zhu H, Wei X, Platt C, Damilano F, Xiao C, Bezzerides V, Bostrom P, Che L, Zhang C, Spiegelman BM, Rosenzwieg A. miR-222 is necessary for exercise-induced cardiac growth annd protects againts pathological cardiac remodeling. Cell Metab. 2005;21(4):584-98; DOI:10.1016/j.cmet.2015.02.014.

67. García-Fernández RA, García-Palencia P, Sánchez MA, Gil-Gómez G, Sánchez B, Rollán E, Martín-Caballero J, Flores JM. Combined loss of p21(waf1/cip1) and p27(kip1) enhances tumorigenesis in mice. Lab. Invest. 2011;91(11):1634-42; DOI:10.1038/labinvest.2011.133.

68. Gabisonia K, Prosdocimo G, Aquaro GD, Carlucci L, Zentilin L, Secco I, Ali H, Braga L, Gorgodze N, Bernini F, Burchielli S, Collesi C, Zandonà L, Sinagra G, Piacenti M, Zacchigna S, Bussani R, Recchia FA, Giacca M. MicroRNA therapy stimulates uncontrolled cardiac repair after myocardial infarction in pigs. Nature. 2019;569(7756):418-22; DOI:10.1038/ s41586-019-1191-6. 